\title{
DOI 10.26886/2520-7474.5(31)2018.2
}

\section{UDC 373.51.001.63}

\section{ACTIVITY AS FACTOR OF PROFESSIONAL SELF-ACTUALIZATION DEVELOPMENT OF PERSONALITY}

\section{R. O. Liashenko, PhD in Pedagogical Sciences}

Volodymyr Vynnychenko Central Ukrainian State Pedagogical University, Ukraine, Kropyvnytskyi

The article deals with the main approaches of the psychologicalpedagogical paradigm to the definition of the content and structure of the category of activity. The main ideas of significant researches on the direction of studying the professional self-actualization of personality and its aspects, in particular, its interrelation with the determining role of activity in the development of personality have been highlighted. It has been proved that the phenomenon of activity is one of the defining factors for effective development of professional self-actualization of the personality, a level of its development and the hierarchy of actions types, which at successively changing stages of personality development become dominant for successful solving of professional tasks.

Keywords: professional self-actualization, personality, activity, selfdevelopment, individual.

Кандидат педагогічних наук, Ляшенко Р. О. Активність як фрактор розвитку профресійної самоактуалізації особистості / Центральноукраїнський державний педагогічний університет імені Володимира Винниченка.

В статті досліджено основні підходи психолого-педагогічної парадигми до визначення змісту і структури категорії активності. Висвітлено основні ідеї вагомих досліджень з напрямку вивчення профресійної самоактуалізації особистості та їі аспектів, зокрема ї 
взаємозв'язку з визначальною роллю активності в розвитку особистості. Доведено, що френомен активності $\epsilon$ одним 3 визначальних фракторів ефрективного розвитку професійної самоактуалізації особистості, рівнем їі розвитку та ієрархією видів діяльності, які на послідовно змінних етапах розвитку особистості стають панівними для успішного розв'язання профресійних завдань.

Ключові слова: профресійна самоактуалізація, особистість, активність, саморозвиток, індивід.

Introduction. The study of the peculiarities of professional selfactualization development of a person requires the study of the content of objective and subjective factors that determine it and necessarily interact with each other. The modern humanist paradigm of education sees the way to the disclosure of the unique potential abilities of a person (to think independently and creatively, to act in non-standard situations professionally and humanely) in the individualization of the educational process in which, the one who studies, acts as an active agent of transformative activity and whose subjective perception of reality, in which this activity takes place, is of priority in relation to its products and the results of the development.

The scientific works comprehensively consider the peculiarities of the development and formation of a creative, socially active personality (V. A. Kan-Kalik, S. O. Sysoev, R. V. Tkach, T. I. Sushchenko, N. V. Kichuk, and others), the possibilities of self-regulation, self-development, selfactualization and self-actualization (K. A. Abulkhanova-Slavska, L. I. Antsiferov, V. P. Zinchenko, O. A. Konopkin, L. A. Korostyleva, D. A. Leontiev, V. I. Slobodchikov, V. V. Stolin, G. Goldstein, E. E. Vakhromov, A. Maslow, K. Rogers, E. Fromm, etc.).

The purpose of the article is to investigate the main approaches of the 
psychological and pedagogical paradigm to the definition of the content and structure of the category of activity, to highlight the main ideas of significant studies in the direction of studying the professional self-actualization of the individual and its aspects, in particular, its relationship with the determining role of activity in the development of personality.

The analysis of scientific literature on the problem "self" makes it possible to assert that the statement of N.R. Bitiaginova that "the phenomenon of self-development remains undiscovered at the stages of adult development" is also relevant today. Most researchers, even if the ontological aspect of the problem of self-realization is not the subject of their special consideration, emphasize its significance in general and the importance of separate age periods in human life from the point of view of the position of this phenomenon [2, p. 3].

The life self-determination of youth who is studying is a complex scientific problem that has a philosophical, sociological, psychological and pedagogical aspect. It is reasonable here to agree with G. P. Nikov, who states, "... a more complicated and responsible in the life of the growing generations is the period when their education is completed under the guidance of adults, and they step on an independent path. This means that the life under the care of the elderly is over, the degree of freedom of young people, their independence in decision-making is expanded; they enter into a time of social maturity ... "[11, p.58].

S. D. Maksymenko considers self-realization as a natural and totally general property (quality) of each person. The need for self-realization is defined as the source of the activity of the individual, which, in particular, determines those activities in which this need will be met in the specific conditions of life [8]. Understanding self-actualization as the ability created during the formation of personal qualities based on natural instincts of human, is presented in the study of J. G. Dolinska [5]. 
Another aspect of activity characterizing the construction of a life strategy is primarily related to initiative and responsibility. A significant amount of scientific research is devoted to the study of the individual characteristics of certain types of social activity, such as professional, educational activities, cognition and communication. The result of these studies is a description of various individual-typological styles of features of activity, cognition, communication.

The main content of the principle of self-development of personality, according to $\mathrm{V}$. O. Tatenko, lies in the fact that the internal (the subject) acts through the external and, thus, changes itself and external [15, p. 308]. Within this principle, the author reveals the technologies of actualization of the subjective potential of the individual $[16,17]$. The supreme and most significant mechanism of self-realization of personality in life is a strategy of life, that is, bringing life in line with one's personality. The strategy of life is an integration, a generalization in the life of what is essential to a given person, and a generalization of what is actually irrelevant to one in reality. Strategy is the realization of life as a system that has an individual character. The strategy is to interact with life during its implementation. It can be a higher vital ability of the individual as its subject, where there integrate the following life's abilities - consciousness, activity (initiative and responsibility) and organization of time. It is these higher (global) vital abilities that integrate into the overall ability to build a strategy [1]. The strategy combines personality, individuality, and subject.

Understanding the problem of self-actualization of the individual as an internal way of self-development, adequate for a person endowed with consciousness, can be considered immanent, invariant feature inherent in all nature, and not just the nature of human. However, considered at the same time that there is a cultural-historical range within which the transition from the problem of self-actualization as a concomitant phenomenon is 
carried out as a compulsory component of any interaction of the system with the environment to the problem of self-actualization as a conscious mode of existence of the individual. Only then self-actualization, but also, accordingly, the problem of self-actualization begins to determine the way of life of the individual, and the multidimensional world of person becomes in one's value coordinates the space for self-realization, self-implementation and self-creation", emphasizes E. V. Galazhynskyi [3, p. 41].

Investigating the self-actualization of the personality of would-be psychologists in teaching and professional activity, N. Starninska understands it as "a continuous dynamic process of actualization and development of potential opportunities of the subject of learning, which ensures the formation of socio-psychological adaptability and reflexivity, which is accompanied by the formation of professional identity and expressed tendency toward productive personality and professional selfchange "[14, p.67].

A. Derkach and E. V. Saiko [4], developing the problems of acmeological development, determine the phenomenon of self-actualization as a need for the implementation of their abilities and talents, creative potentials, etc.

In general, the self-actualization can be understood in different aspects: dynamically, as a process of identifying or stimulating internal conflicts of self-development, understanding and solving of existential problems, which leads to the transition of individual, personality and subjective qualities of a person from the potential to the actual state, that is, to their self-development, and thus ensuring the beginning of a new stage of self-realization; in the content plan - as an integrative personal quality that ensures the person's readiness and ability to overcome internal contradictions in the process of self-development, mobilize their acmeological resources for the creative implementation of life plans and 
programs and the effective solution of personal and professional tasks.

Summarizing different views of scientists on this problem, it can be observed that most of them see the problem of self-actualization and selfactualization as particularly important, as it is associated with the selfactualization of a person; there is a need to consider the features of the combination of internal stimuli and external conditions of self-development.

Consequently, self-actualization can be regarded as a specific type of integrative personal competence, that is, as an integrative personal quality that mediates all kinds of purposeful activity of a person, allows it to act independently and responsibly, provides the formation of a productive life activity algorithm and provides an increase in its efficiency.

Therefore, G. S. Sullivan considers personality as an energy system whose activity reduces stress [12]. One of the components of the personality is dynamism - stable patterns of transformed energy. An important dynamism associated with interpersonal relationships is the dynamism "I" or the system "I".

The explanation of the phenomenon of activity, as a rule, is carried out in terms of autonomy, spontaneity, self-satisfaction, initiative, etc. Any detection of activity takes place in a certain environment. In this connection, there are two approaches to the use of the term "activity" and, accordingly, its two values: as a creative party of any process of interaction or action, which is conditioned by the internal nature of the object; as a process, the peculiarity of which is determined, first of all, by the internal determination of the object, its self-assertion, that is, the internal determination dominates the external.

Activity in the second sense is inherent only in living systems. Therefore, there are no absolutely active or absolutely passive processes, any of them is the result of external and internal reasons. A way of resolving the contradictions between them is the reflection. The progressive solution 
of contradiction causes an increase in the proportion of the internal condition of the object and lies not in the spontaneous growth of the object's self, its maturing inside as a closed whole, but in the transfer of external factors to the inside, by their reflection and fixation in more complex forms of the inner organization. "Reflection is the mechanism by which an organism transforms external determinants into moments of selfdetermination" [7, p. 141].

Personality activity is a unity of reflection of the expression and realization of external and internal tendencies in society. The active person is most capable of demonstrating a valuable way of modeling the content of socially meaningful activity, communication and behavior, in which the person acquires the possibility of independent existence as a system in the interpersonal space. In the process of development of activity, the person performs an active search, creates and transforms the conditions of satisfaction of socially important needs in accordance with the personal position, its values and requirements applied to it. Hence, personal activity is a personal way of comparing oneself with others, determining one's position.

A. Maslow [9, 10] names significant personality characteristics effective perception of reality and comfortable relationship with it; acceptance of oneself, others, of nature; spontaneity, simplicity, ingenuousness; servicing; denial, need for union; autonomy, independence from culture and environment, freedom and activity; a fresh look at things; mystical and higher excitement; a sense of community; deep interpersonal relationships; democracy; the ability to distinguish means from the purpose, good from evil; philosophical sense of humor; creativity; leadership in life of everyday values.

The notion of self-realization by E. Fromm [18] implies the presence of productive activity associated with satisfaction of a number of needs: in 
establishing ties, capture, unity with the world; in transcendence, which is connected with the feeling of freedom and its own significance; in the roots as an ability to feel part of the world; in identity with oneself and others; in the system of orientation, necessary for the possibility to act purposefully.

The activity serves the most complete development of the inner world of the individual. An important indicator of a high level of activity is the correspondence of conscious, purposeful, active and creative attitude of the person to the activity. The quality of the individual's activities in the environment of one's life is manifested in social activity. Demonstration of social activity of the individual consists in transformation and self-activity in all spheres of social life. On the basis of this self-determination, selfexpression, self-affirmation, self-government and self-education of the individual are formed.

As V. F. Safin rightly observes, responsibility is a determining and systematic sign of individual self-determination. He emphasizes: "... an individual who self-determined is an entity that knowingly and continuously compares one's own purpose with the aim of a group, a society that is able to actively defend one's ideals. Thus, self-determination is a process, which is a relatively independent stage of socialization, the significance of which consists in the formation of an awareness of the purpose and content of life, of the readiness for independent life through the correlation of one's desires, the qualities, possibilities and requirements applied to it by the surrounding people and society "[13, p.151]. V. Safin also believes that "the higher level of responsibility, as the leading moral property, is a concept that is directly related to the outlook of the individual. It has a connection with such moral concepts as humanism, patriotism, honesty, initiative, discipline, conscientiousness, hard work, creative activity, ability to act, reasonable self-restraint "[13, p.115].

The emergence of internal responsibility, its transformation into the 
social quality of a person depends on the activity and self-determination of a person, its psychological and intellectual features. According to $\mathrm{S}$. Kulikovskyi's characteristic "As human activity, responsibility is possible only in the society, only on the objective basis of relations between people and therefore, it is initially social in nature" [6, p.11].

The category of activity is often associated with the category of reflection and discussed about the activity of mental reflection, activity of consciousness. Some authors believe that activity is an attribute of reflection in wildlife and social life; others regard activity as an independent attribute of the psyche, of consciousness, along with an attribute of reflection. The activity of mental reflection can be manifested in phenomena of different nature and different levels, as intrinsically psychic (from feeling to the outlook), and in internal discoveries (from simple motor reactions to complex social behavior, activities, and practices).

Conclusions. Personal activity reflects the contradiction and unity of social and individual human needs. In activity, the focus is on serving the interests of society, the professional community, forming the acquisition of knowledge needed to engage in active work. The phenomenon of activity is one of the defining conditions for effective development of professional selfactualization of the personality, a level of its development and the hierarchy of actions types, which at successively changing stages of personality development become dominant for successful solving of professional tasks.

\section{תimepamypa:}

1. Абульханова К. А. Стратегия жизни / К. А. Абульханова. М.:Мысль, 1991.

2. Битягинова Н. Р. Проблема саморазвития личности в психологии: Аналитический обзор / Н. Р. Битягинова. - М.: МПСИ: Флинта, 1998. 
3. Галажинский Э. В. Системная детерминация самореализации личности: Дисс. ... д-ра психол. наук / Э. В. Галажинский. - Томск, 2002.

4. Деркач А. А. Развитие в акмеологии и акмеологическое развитие в структуре онтогенеза / А. А. Деркач, Э. В. Сайко // Мир психологи. 2007. - №2. - C.43-55.

5. Долінська Ю.Г. Самоактуалізація особистості майбутнього психолога у процесі профресійної підготовки: дис. ... канд. психол. наук: 19.00.07 / Долінська Юлія Георгіївна. - К., 2000. - 200 с.

6. Куликовский С. В. Формирование социально-политической ответственности личности: автор, дисс. на соискание научной степени канд. фрилос. наук.: С. В. Куликовский. - КГУ им. Т.Г. Шевченко. - К., 1989. - 22 с.

7. Ляхова Л. Н. Отражение и активность материи / Л. Н. Ляхова Саратов, 1979.

8. Максименко С.Д. Психологія особистості: Підручник / С. Д. Максименко, К. С. Максименко, М. В. Папуча. - К.: ТОВ «КММ», 2007. -296 C.

9. Маслоу А. Мотивация и личность / А. Маслоу. - СПб.: Евразия, 1999. - 479 c.

10. Маслоу А. Психология бытия: Пер. С англ. - М.: Рефлл-бук; Киев: Ваклер, 1997.

11. Ников Г.П. Жизненное самоопределение как педагогическая проблема / Г. П. Ников // Вопросы самоопределения личности и ее активность.- Уфра, 1985. - С.58-64.

12. Салливэн Г. С. Межличностная теория психиатрии / Г. С. Салливэн // История зарубежной психологии / [ред. П. Я. Гальперин, А. Н. Ждан]. - М., 1986. - С. 172-185. 
13. Сафрин В.Ф. Проблема самоопределения личности педагога / В.Ф. Сафин // Формирование социальной активности личности учителя: Межвуз. Сб. научных трудов / под ред. В. А. Сластенина. Московский государственный: пединститут им. В. И. Ленина. - М., 1982. - C. 148-153.

14. Старинська Н. В. Особливості самоактуалізації майбутніх психологів у процесі профресійної підготовки / Наталія Володимирівна Старинська. - Київ:"Інтерсервіс", 2015. - 178 с.

15. Татенко В.А. Пихологические стратегии и технологии актуализации субъективного потенциала человека / В. А. Татенко// Психологія на перетині тисячоліть: Матеріали П'ятих Костюківських читань (1999р.). В 3-х т. - К., 1999. - Т.3.

16. Татенко В.А. Психология в субъектном измерении: Монографрия/ В. А. Татенко. - К.: Видавничий центр „Просвіта”, 1996. $-404 c$.

17. Татенко В. А. Субъект психологической активности: поиск новой парадигмы / В. А. Татенко // Психол. журнал. - 1995. - Т. 16, № 3. C. 64-70.

18. Фромм Э. Иметь или быть / Э. Фромм. - М., 1986.

\section{References:}

1. Abulkhanova K. A. Strategiya zhizni / K. A. Abulkhanova. M.:Mysl, 1991.

2. Bityaginova N. R. Problema samorazvitiya lichnosti v psikhologii: Analiticheskiy obzor / N. R. Bityaginova. - M.: MPSI: Flinta, 1998.

3. Galazhinskiy E. V. Sistemnaya determinatsiya samorealizatsii lichnosti: Diss. ... d-ra psikhol. nauk / E. V. Galazhinskiy. - Tomsk, 2002.

4. Derkach A. A. Razvitie $v$ akmeologii i akmeologicheskoe razvitie $v$ strukture ontogeneza / A. A. Derkach, E. V. Sayko // Mir psikhologi. - 2007. - №2. - S.43-55. 
5. Dolinska Yu. H. Samoaktualizatsiia osobystosti maibutnoho psykholoha u protsesi profesiinoi pidhotovky: dys. ... kand. psykhol. nauk: 19.00.07 / Dolinska Yuliia Heorhiivna. - K., 2000. - 200 s.

6. Kulikovskiy S. V. Formirovanie sotsialno-politicheskoy otvetstvennosti lichnosti : avtor, diss. na soiskanie nauchnoy stepeni kand. filos. nauk.: S. V. Kulikovskiy. - KGU im. T.G. Shevchenko. - K., 1989. - 22 s.

7. Lyakhova L. N. Otrazhenie i aktivnost materii / L. N. Lyakhova Saratov, 1979.

8. Maksymenko S. D. Psykholohiia osobystosti: Pidruchnyk / S. D. Maksymenko, K. S. Maksymenko, M. V. Papucha. - K.: TOV «KMM», 2007. $-296 s$.

9. Maslou A. Motivatsiya i lichnost / A. Maslou. - SPb.: Yevraziya, 1999. $-479 s$.

10. Maslou A. Psikhologiya bytiya: Per. S angl. - M.: Refl-buk; Kiev: Vakler, 1997.

11. Nikov G. P. Zhiznennoe samoopredelenie kak pedagogicheskaya problema / G. P. Nikov // Voprosy samoopredeleniya lichnosti $i$ ee aktivnost.- Ufa, 1985. - S.58-64.

12. Salliven G. S. Mezhlichnostnaya teoriya psikhiatrii / G. S. Salliven // Istoriya zarubezhnoy psikhologii / [red. P. Ya. Galperin, A. N. Zhdan]. - M., 1986. - S. $172-185$.

13. Safin V. F. Problema samoopredeleniya lichnosti pedagoga / V. F. Safin // Formirovanie sotsialnoy aktivnosti lichnosti uchitelya: Mezhvuz. Sb. nauchnykh trudov / pod red. V. A. Slastenina. - Moskovskiy gosudarstvennyy: pedinstitut im. V. I. Lenina. - M., 1982. - S. 148-153.

14. Starynska N. V. Osoblyvosti samoaktualizatsii maibutnikh psykholohiv u protsesi profesiinoi pidhotovky / Nataliia Volodymyrivna Starynska. Kyiv:"Interservis", 2015. - 178 s. 
15. Tatenko V. A. Pikhologicheskie strategii i tekhnologii aktualizatsii subektivnogo potentsiala cheloveka / V. A. Tatenko // Psikhologiya na peretini tisyacholit: Materiali P'yatikh Kostyukivskikh chitan (1999 r.). V 3-kh t. - K., 1999. - T.3.

16. Tatenko V. A. Psikhologiya v subektnom izmerenii: Monografiya / V.

A. Tatenko. - K.: Vidavnichiy tsentr „Prosvita”, 1996. - 404 s.

17. Tatenko V. A. Subekt psikhologicheskoy aktivnosti: poisk novoy paradigmy / V. A. Tatenko // Psikhol. zhurnal. - 1995. - T. 16, № 3. - S. 64-70.

18. Fromm E. Imet ili byt / E. Fromm. - M., 1986. 